\title{
Nilai-Nilai Pendidikan Dari Adanya Term Muhkam dan Mutasyabih dalam Tafsir Al-Qur'an
}

\author{
H. Zainal Arifin Munir \\ Universitas Islam Negeri Mataram \\ E-mail : zainyanmu@ uinmataram.ac.id \\ Adet Tamula Anugrah \\ Universitas Islam Negeri Sunan Kalijaga Yogyakarta \\ E-mail : adettamula@gmail.com
}

\begin{abstract}
This study was conducted to analyze the concept of muhkam and mutasyabih and educational values contained in both terms. The terms muhkam and mutasyabih are rarely understood by teachers as educators in the learning process. These terms are only understood by those who specifically study and analyze the Qur'an in deeply. Because basically the Qur'an is the main reference in Islamic education. So teachers should understand how the concept of muhkam and mutasyabih and understand the values that can be derived from the classification of Qur'anic verses based on these two terms. The research conducted in this paper is a literature approach. The results of this analysis reveal that there are differences of opinion among scholars in analyzing the holy verses of the Qur'an, especially on verses that fall into the mutasyabihat category. From these differences of opinion, the educational values that can be derived from the existence of muhkam and mutasyabih are tolerance values, mujahadah values, tauhid values, and contextual education values.
\end{abstract}

Keywords: Muhkam, Mutasyabih, Education

\begin{abstract}
Abstrak
Penelitian ini dilakukan untuk menganalisis konsep muhkam dan mutasyabih serta nilai-nilai pendidikan yang terdapat dalam kedua term tersebut. Istilah muhkam dan mutasyabih jarang difahami oleh guru selaku tenaga pengajar dalam prosesm pembelajaran. Kedua term ini hanya difahami oleh mereka yang khusus mengkaji dan menganaslis Al-Qur'an secara mendalam. Karena pada dasarnya AlQur'an adalah rujukan utama dalam pendidikan Islam, maka seyogyanya guru harus mengerti bagaimana konsep muhkam dan mutasyabih serta memahami nilai-nilai yang bisa dipetik dari adanya pengklasifikasian ayat-ayat Al-Qur'an berdasarkan kedua term tersebut. Penelitan yang dilakukan dalam tulisan ini adalah pendekatan kepustakaan. Hasil dari analisis ini mengungkapkan bahwa terdapat perbedaan pendapat para ulama dalam menganalsis ayat-ayat suci Al-Qur'an, terutama pada ayat-ayat yang masuk dalam kategori mutasyabihat. Dari perbedaan pendapat tersebut nilai-nilai pendidikan yang dapat dipetik dari adanya muhkam dan mutasyabih adalah nilai toleransi, nilai mujahadah, nilai tauhid, dan nilai pendidikan kontekstual.
\end{abstract}

Kata Kunci : Muhkam, Mutasyabih, Pendidikan

\section{Pendahuluan}

Al-Qur'an merupakan wahyu yang diturunkan kepada Nabi Muhammad SAW. dan menjadi mukjizat terbesar dalam perjalanan ke-Rasulan beliau. Keagungan AlQur'an dapat dilihat dari eksistensi dan kemurniannya yang tetap terjaga sampai saat ini, dan bahkan selalu dapat membaca perkembangan kehidupan manusia dari zaman ke zaman. Autentisitas dan fleksibelitas yang dimiliki, menjadi keabsahan Al-Qur'an 
sebagai rujukan dan sumber utama bagi manusia dalam menghadapi dinamika kehidupan. Al-Qur'an bukan hanya memanage hubungan vertikal manusia dengan Tuhan, tetapi Al-Qur'an juga menjadi rujukan utama berbagai macam ilmu pengetahuan yang diperlukan oleh umat manusia. ${ }^{1}$

Sebagai sumber yang relevan dengan perkembangan hidup manusia baik dari aspek spiritualitas maupun ilmu pengetahuan, makna eksplisit maupun implisit dari setiap ayat-ayat Al-Qur'an harus bisa difahami. Dalam upaya memahami ayat-ayat AlQur'an memang memiliki tingkat yang berbeda. Ada ayat-ayat yang mudah difahami, dan ada juga ayat-ayat yang sulit untuk difahami. pengklasifikasian ayat-ayat tersebut, dalam ilmu tafsir dikenal dengan sebutan muhkam dan mustasyabih.

Ayat-ayat muhkamat adalah ayat-ayat suci Al-Qur'an yang dapat difahami dengan mudah, karena makna dan maksud dari ayat tersebut sangat terang dan tegas tercantum sehingga memahaminya hanya dengan membacanya. Adapun ayat-ayat mutasyabihat adalah ayat-ayat yang dapat dikatakan cukup sulit untuk memahaminya, karena ayat-ayat mutasyabihat mengandung beberapa makna dan tidak bisa ditentukan apa makna sebenarnya kecuali dengan mengkaji dan menelitinya secara mendalam. ${ }^{2}$ Pengklasifikasian antara ayat-ayat muhkamat dan mutasyabihat memiliki pengaruh bagi berbagai aspek kehidupan manusia, terutama dalam bidang pendidikan. Hal ini dikarenakan Al-Qur'an sangat berpengaruh bagi perkembangan pendidikan dalam dunia Islam.

Kedudukan Al-Qur'an sebagai salah satu pembangun peradaban keilmuan dapat dilihat dari perubahan pola pikir masyarakat yang dulunya jahiliyah bertransformasi menjadi masyarakat yang maju dan mengungguli bangsa lain. Sehingga sangat pantas dikatakan bahwa Al-Qur'an merupakan kitab pendidikan dan pengajaran. Tujuan pokok Al-Qur'an yang menjadi pedoman ummat Islam adalah untuk memperbaiki individu dan sosial, sehingga ummat Islam menjadi bangsa yang memiliki kedewasaan dalam

\footnotetext{
${ }^{1}$ Oom Mukarromah, Ulumul Qur'an (Jakarta: PT RajaGrafindo Persada, 2013), 1.

${ }^{2}$ Yunahar Ilyas, Kuliah Ulumul Qur'an, 3rd edn (Yogyakarta: ITQAN Publishing, 2014), 192193.
} 
berfikir, kecerdasan akal budi, kebersihkan jiwa, serta terwujudnya persaudaraan ditengah-tengah ummat Islam itu sendiri. ${ }^{3}$

Pada uraian ini penulis melakukan kajian tentang term muhkam dan mutasyabih, mulai dari pengertian secara umum, kemudian klasifikasi dan implikasi dari adanya pengklasifikasian term muhkam dan mutasyabih bagi peradaban ummat Islam, serta analisis mengenai nilai pendidikan atas pengklasifikasian ayat muhkam dan mutasyabih. Kajian ini dilakukan mengingat Al-Qur'an yang merupakan rujukan pertama dalam dunia pendidikan Islam. Sehingga tujuan yang hendak dicapai adalah meningkatkan ghirah untuk mengkaji ilmu ke-Islaman lebih dalam dan dapat melahirkan kebijaksanaan dalam menilai berbagai perspektif pengkajian Al-Qur'an terutama dalam konteks pendidikan Islam.

Penilitian ini menggunakan pendekatakan kepustakaan. Penelitian kepustakaan adalah penelitian yang dilakukan berdasarkan karya tulis, dalam hal ini termasuk hasil penelitian yang tertulis baik itu sudah ataupun belum dipuklikasikan. Sehingga penelitian ini tidak memerlukan terjun ke lapangan secara langsung, akan tetapi cukup dengan pemanfaatan berbagai sumber kepustakaan dalam memperoleh data penelitian. ${ }^{4}$

\section{Pengertian Muhkam dan Mutasyabih}

Secara etimologi muhkam berasal dari kata حكم yang memiliki 5 makna yaitu ; bermakna منع yaitu melarang dalam rangka untuk kebaikan, حَكَمَة yaitu maknanya kekang atau kendali yang dipasang pada leher binatang, الحكم , حِكْمَ, artinya kebijaksangaang bermakna memisahkan dua hal, yang bermakna إحكام الكلام mengokohkannya dengan cara memisahkan berita yang benar dari berita yang salah, dan memisahkan yang lurus dari yang sesat. Secara keseluruhan Al-Qur'an bersifat muhkam, dalam arti ayat-ayat Al-Qur'an secara keseluruhan bersifat fasih, kokoh, jelas dan indah. Bersifat muhkam juga memiliki makna bersifat membedakan perkara yang hak dan yang batil dan antara

${ }^{3}$ Mahmud Arif, Tafsir Pendidikan Makna Edukasi Alquran Dan Aktualisasi Pembelajarannya (Yogyakarta: Penerbit Ombak, 2015), 16-17.

${ }^{4}$ Melfianora, 'Penulisan Karya Tulis Ilmiah Dengan Studi Literatur', Open Science Framework, 
perkara yang benar dan yang dusta. Inilah yang dimaksud dengan muhkam secara umum. ${ }^{5}$ Adapun mutasyabih berasal dari kata شبه yang maknaya kemiripan atau keserupaan (ماثلة) antara satu hal dengan hal yang lain. Makna ini dapat dilihat dari ayat

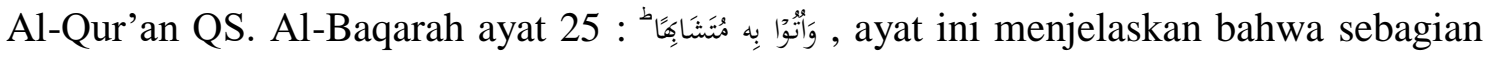
buah-buahan yang di dalam syurga serupa antara satu sama lain dalam hal warna, sedangkan rasa dan hakikatnya tidak serupa (berbeda). ${ }^{6}$

Secara terminologi, ada beberpa pengertian muhkam dan mutasyabih, diantaranya $^{7}$ : Pertama, Muhkam adalah ayat Al-Qur'an yang memiliki makna jelas, sedangkan mutasyabih merupakan ayat yang memerlukan pemikiran dan pengkajian untuk memahami maknanya. Kedua, Muhkamat merupakan ayat-ayat yang dapat diketahui dan difahami dengan jelas berdasarkan fenomena (tanda) yang jelas maupun samar, sedangkan mutasyabihat merupakan ayat-ayat yang tidak dapat diketahui bagaimana fenomena terjadinya, seperti penjelasan mengenai hari kiamat, neraka, dan surga. Ketiga, Muhkam adalah kelompok ayat yang tidak memerlukan dita'wil, dan mutasyabih adalah kelompok ayat yang memerlukan ta'wil.

Keempat, Muhkamat adalah ayat-ayat yang wajib untuk diimani serta diamalkan, sedangkan mutasyabihat adalah ayat-ayat yang hanya perlu diimani dan tidak wajib untuk diamalkan. Kelima, Muhkamat adalah ayat-ayat yang memiliki makna eksplisit (sesuai dzahir ayat), sedangkan mutasyabihat merupakan ayat-ayat yang memiliki makna implisit (makna lain diluar dzahir ayat). Keenam, Muhkam adalah ayat yang makna dan pengertiannya disepakati, dan mutasyabih adalah ayat yang makna dan pengertiannya terdapat perbedaan untuk disepakati. Ketujuh, Muhkamat adalah ayatayat mudah untuk ditafsirkan, sedangkan mutasyabihat adalah ayat-ayat yang sulit ditafsirkan baik itu lafadz ataupun makna.

Dari beberapa definisi diatas, dapat difahami bahwa antara ayat muhkam dan ayat mutasyabih memiliki perbedaan baik itu dari segi lafadz atapaun makna. Ayat-ayat

\footnotetext{
${ }^{5}$ Ahmad Sarwat, Muhkam Dan Mutasyabih (Jakarta Selatan: Rumah Fiqih Publishing, 2020), 1-3.

${ }^{6}$ Mohammad Nor Ichwan, Memahami Bahasa Al-Qur'an, 2nd edn (Yogyakarta: Pustaka Pelajar, 2018), 254

${ }^{7}$ Ichwan, 254-256.
} 
muhkamat adalah ayat-ayat yang dapat difahami dengan mudah, sehingga tidak perlu melakukan analisis yang mendalam untuk menggali maksud dan maknanya. Adapun ayat-ayat mutasyabihat adalah ayat-ayat yang sulit untuk difahami lafadz dan maknanya jika tidak dilakukan analisis secara mendalam.

\section{Klasifikasi dan Implikasi Adanya Ayat-Ayat Muhkamat dan Mutasyabihat}

Ayat-Ayat Muhkamat adalah ayat-ayat Al-Qur'an yang tersusun dengan rapi dan terperinci. Konsep ini sesuai dengan pengertian muhkam yang tercantum dalam QS.

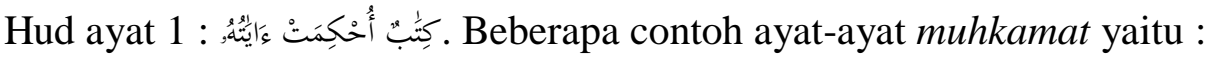

1. QS. Al-Baqarah ayat 43

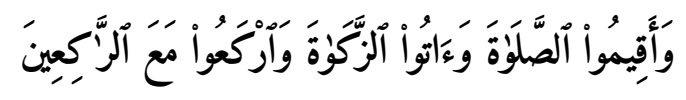

"Dan laksanakanlahlah shalat, tunaikanlah zakat dan rukuklah beserta orang yang rukuk"'

2. QS. Al-Baqarah ayat 275

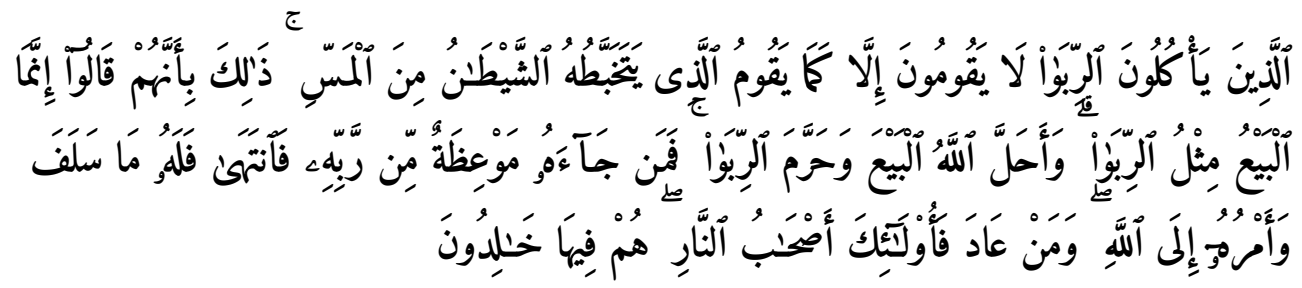

"Orang-orang yang makan (mengambil) riba tidak dapat berdiri melainkan seperti berdirinya orang yang kemasukan syaitan lantaran (tekanan) penyakit gila. Keadaan mereka yang demikian itu, adalah disebabkan mereka berkata (berpendapat), sesungguhnya jual beli itu sama dengan riba, padahal Allah telah menghalalkan jual beli dan mengharamkan riba. Orang-orang yang telah sampai kepadanya larangan dari Tuhannya, lalu terus berhenti (dari mengambil riba), maka baginya apa yang telah diambilnya dahulu (sebelum datang larangan); dan urusannya (terserah) kepada Allah. Orang yang kembali (mengambil riba), maka orang itu adalah penghuni-penghuni neraka; mereka kekal di dalamnya." 
3. QS. At-Tin ayat 3

"Dan demi kota (Mekah) ini yang aman,"

Ayat-ayat mutasyabihat meruapakan ayat-ayat yang memiliki kesamaran makna (tasyabuh) baik itu dari lafadz ataupun maknanya. Ayat-ayat mutasyabihat terbagi menjadi 3 kelompok, yaitu :

\section{Tasyābuh pada Lafal Ayat}

Kondisi ini terjadi karena tiga sebab, pertama karena lafal yang digunakan adalah gharib yang artinya lafal yang digunakan oleh ayat Al-Qur'an menggunakan kosa kata yang jarang bahkan tidak digunakan oleh bangsa Arab pada umumnya. Contohnya adalah penggunaan kata ị pada surat 'Abasa ayat 31.

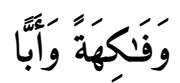

Makna kata tersebut bahkan tidak bisa dijelaskan oleh Abu Bakr as-Shiddiq dan 'Umar ibn Khattab karena kata tersebut tidak pernah didengar oleh orang-orang Arab pada umumnya. ${ }^{8}$

Kedua terjadi karena kata dalam ayat bersifat musytarak (memiliki makna lebih dari satu). Contohnya adalah penggunaan kata قُرْوَّ pada surat Al-Baqarah ayat 228.

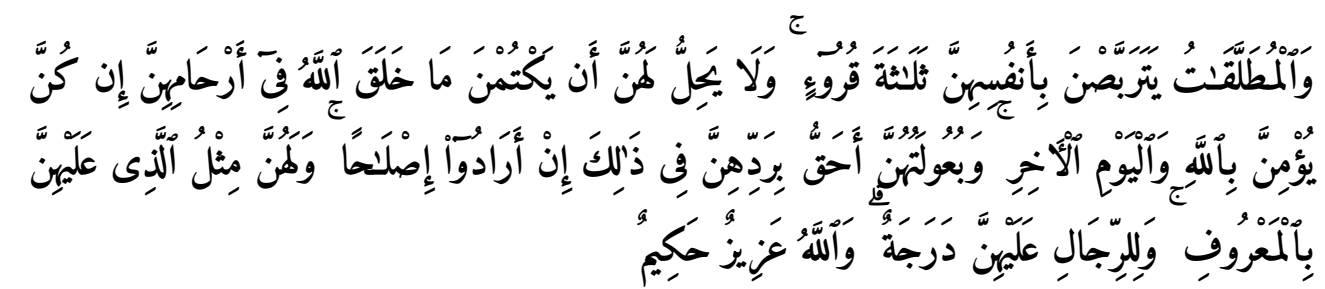

Kata قُرُْو bisa bermakna haidh dan bisa bermakna suci. ${ }^{9}$

Ketiga, karena susunan kalimat (tarkib al-kalimat) yang digunakan terlalu ringkas, terlalu luas, dan ada susunan kalimat yang secara dzahir tidak berurutan. Contoh ayat yang menggunakan redaksi teralu ringkas adalah surat An-Nisa ayat 3.

\footnotetext{
${ }^{8}$ Ilyas, 194-195.

${ }^{9}$ Ilyas, 195-196.
} 


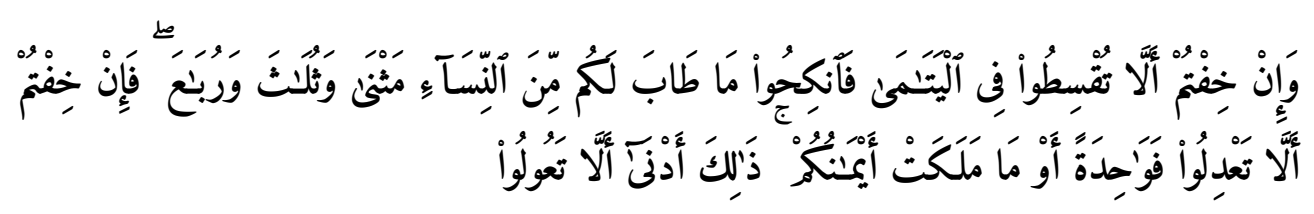

Susunan kalimat yang digunakan dalam ayat tersebut terlalu ringkas. Secara sederhana makna yang dapat dimengerti dari susunan kalimat tersebut adalah, jika takut tidak adil kepada anak-anak yatim, maka menikahlah dengan wanita yang baik-baik maksimal empat. Namun jika takut tidak berlaku adil, maka nikahi satu wanita saja. Pertanyaan yang muncul dari redaksi kalimat ayat ini adalah, apa hubungan antara takut berlaku tidak adil kepada anak yatim dan menikahi wanita ?. Ayat tersebut memiliki susunan kalimat yang sangat ringkas, sehingga tidak mudah untuk mengerti makna yang sebenarnya. ${ }^{10}$

Contoh ayat yang memiliki makna cukup luas adalah pada QS Asy-Syūra ayat 11

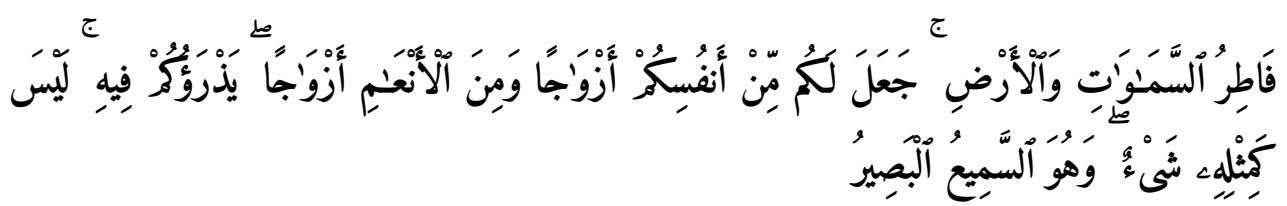

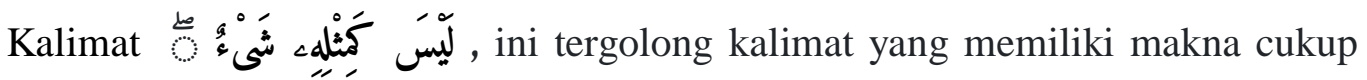
luas. Ayat ini menggunkan huruf kaf ditambah dengan kalimat mitsl. Padahal makna dari keduanya adalah untuk mempersamakan sesuatu dengan yang lain. Sehingga para Mufassir, menjelaskan makna kalimat ini adalah penguat ( $t a$ 'kid), sehingga makna dari kalimat ini adalah , "sungguh sama sekali tidak ada sesuatu yang serupa dengan-Nya. ${ }^{11}$

Contoh ayat yang susunan kalimatnya tidak berurutan sesuai dengan kebiasaan Bahasa Arab pada QS Al-Kahfi ayat 1-2

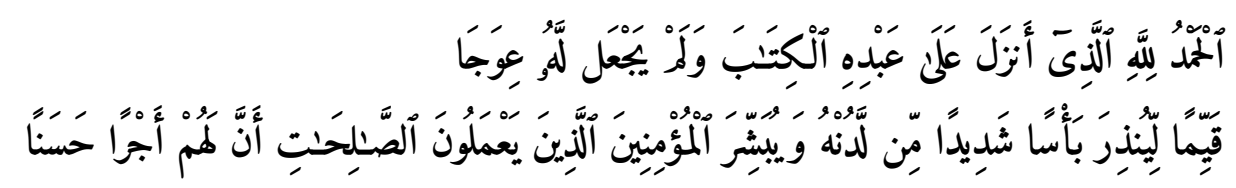

Pada redaksi ayat ini, tertera kata qayyiman berada setelah kata al-Kitāb. Sedangkan qayyiman adalah kata sifat dari al-Kitāb. ${ }^{12}$

\footnotetext{
${ }^{10}$ Ilyas, 196-197.

${ }^{11}$ Ilyas, 197-198.

12 Ilyas, 198.
} 


\section{Tasyabuh pada Makna Ayat}

Kondisi ini terjadi ketika membicarakan hal-hal gaib, seperti sifat-sifat Allah SWT., dan hal-hal lain yang berkaitan dengan kehidupan setelah di dunia. Sekalipun bisa dimengeti arti kata-katanya, tetapi tidak akan bisa mengerti makna implisit dari redaksi ayatnya. Contoh ayat-ayat yang termasuk ke dalam kategori ini sangat banyak sehingga tidak perlu untuk dikutip. ${ }^{13}$

\section{Tasyabuh pada Lafal serta Makna Ayat}

Tasyabuh pada konteks ini terjadi pada lafal serta makna dari ayat. Contohnya pada QS Al-Baqarah ayat 189,

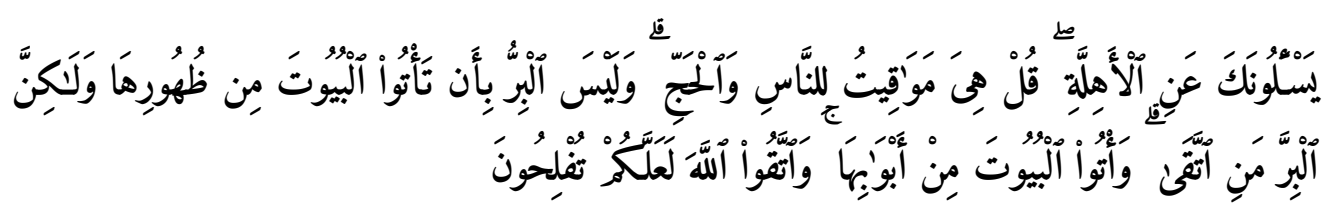

Asbabunnuzul dari ayat ini adalah ketika beberpa kaum Anshar berihram untuk haji, mereka tidak memasuki rumah melalui pintu, tetapi mereka membuat lobang dibelakang rumah, kemudian keluar masuk melalui lubang itu, sehingga ditegurlah oleh Allah SWT. melalui ayat ini. Lafal pada ayat ini sangat ringkas dan begitu pula maknanya sangat sulit dimengerti terutama oleh orang-orang tidak mengerti kebiasaan bangsa Arab dahulu. Setelah mengetahui asbabunnusul dan mengetahui kebiasaan bangsa Arab, baru bisa dimengerti apa makna yang terkandung dari ayat tersebut. Sehingga ayat ini dikatakan tasyabuh dari segi lafal dan maknanya sekaligus. ${ }^{14}$

Implikasi dari adanya klasifikasi muhkam dan mutasyabih terhadap peradaban ummat Islam adalah, ummat Islam akan selalu berusaha untuk mengkaji dan mengungkap makna dari ayat-ayat Al-Qur'an, sehingga akan menambah pahala bagi mereka. Jika dalam Al-Qur'an hanya mengandung ayat-ayat muhkamat, maka nantinya hanya akan ada satu mazhab keilmuan dalam memahami Al-Qur'an, dan jika ada perbedaan pemahaman, maka pemahaman tersebut akan ditolak, terlebih dalam menafsirkan, maka nantinya hanya akan ada penafsiran menggunakan ayat-ayat muhkamat tersebut. Apabila tradisi penafsiran hanya bertahan dengan kondisi demikian,

\footnotetext{
${ }^{13}$ Ilyas, 198-199.

${ }^{14}$ Ilyas, 199-200.
} 
maka tidak akan ada pengembangan keilmuan dalam Islam, sehingga agama islam nantinya akan dianggap sebagai agama yang tekstual. Ayat-ayat mutasyabihat mendorong ummat untuk melakukan pengkajian, sehingga untuk mengkaji ayat-ayat tersebut, sangat dibutuhkan ilmu-ilmu lain, seperti ilmu Bahasa, ilmu gramatika, dan ilmu-ilmu lainnya. Seaindainya tidak ada ayat-ayat mutasyabihat maka bisa prediksi bahwa ilmu-ilmu tersebut tidak akan lahir.

Adanya kedua term ini sangat membantu dalam dunia dakwah. Ummat yang tergolong awam, maka mereka tidak akan menyukai sesuatu yang abstrak, mereka harus diberikan penjelasan yang empirik mengenai hakikat dari ayat-ayat Al-Qur'an. Sehingga dengan ini, ayat-ayat yang membahas sifat-sifat Tuhan akan dapat dijelaskan maknanya dan kemudian dibuktikan secara empirik dengan ayat-ayat muhkamat. ${ }^{15}$ Ayat-ayat muhkamat dan mutasyabihat sangat membantu ummat Islam, baik dalam aspek ilmu pengetahuan, aspek dakwah, dan terutama aspek spiritualitas.

\section{Pandangan Ulama Mengenai Muhkam dan Mutasyabih}

Ayat-ayat muhkamat dan mutasyabihat di satu sisi memiliki kedudukan yang sama, namun di sisi lain memiliki kedudukan yang berbeda. Di satu sisi keduanya dapat dijadikan hujjah. Karena ayat-ayat Al-Qur'an yang diturunkan ada yang masuk ke dalam kategori muhkam dan ada yang masuk ke dalam kategori mutasyabih. Dalam konteks ini, keduanya memiliki kedudukan yang sama. Akan tetapi jika dianalisis lebih dalam, ayat-ayat muhkamat adalah ayat-ayat yang mengandung makna tidak lebih dari satu, dan tidak ada perbedaan ataupun perdebatan mengenai makna ayat-ayat tersebut. Sedangkan ayat-ayat mutasyabihat membutuhkan analisis yang lebih dalam untuk mengetahui maknanya, sehingga kerap kali terjadi perbedaan pendapat dalam menafsirkan makan dari ayat-ayat mutasyabihat. Dengan kondisi yang demikian maka dapat difahami bahwa antara muhkam dan mutasyabih memiliki kedudukan yang berbeda. $^{16}$

15 Amroeni Drajat, Ulumul Qur'an Full Pengantar Ilmu-Ilmu Al-Qur'an, 1st edn (Depok: KENCANA, 2017), 100-101.

${ }^{16}$ Miftahur Rohman, 'Konsep Muhkam Dan Mutasyabih Dalam Alqur'an Menurut Muhammad 'Abid Al-Jabiri', Hermeneutik, 12.1 (2019), 175-88 <https://doi.org/10.21043/hermeneutik.v12i1.6072>. 
Perbedaan kedudukan antara kedua term tersebut menimbulkan perbedaan pendapat ulama'. Perbedaan tersebut setidaknya menyangkut pada 3 hal. Pertama, mengenai penentuan ayat-ayat muhkamat dan mutasyabihat. Perbedaan ini terjadi ketika ada ayat-ayat yang diakui oleh satu kelompok sebagai ayat-ayat muhkamat, akan tetapi ayat-ayat tersebut dianggap sebagai ayat-ayat mutasyabihat oleh kelompok lain. Contohnya adalah ayat mengenai deskripsi surge dan neraka, bagi kebanyakan umat Islam ayat-ayat terbesut masuk ke dalam kategori muhkamat, tapi ada kelompok yang meyakini bahwa ayat-ayat tersebut masuk ke dalam kategori mutasyabihat sehingga terjadilah perbedaan penafsiran. ${ }^{17}$

Kedua, mengenai boleh tidaknya menta'wil ayat. ${ }^{18}$ Kelompok salaf atau kelompok ulama mutaqaddimin mengambil sikap lebih hati-hati terhadap kesalahan mereka dalam menafsirkan ayat-ayat Al Qur'an, terutama ayat-ayat mutasyabihat. Mereka mengimani ayat-ayat mutasyabihat dan meyerahkan sepenuhnya kepada Allah Swt tanpa melakukan interpretasi yang mendalam. Sikap tersebut berbeda dengan sikap kelompok khalaf atau ulama mutaakkhirin. Kelompok ini melakukan interpretasi mendalam dengan metode menta'wil ayat-ayat mutasyabihat dengan menentukan maknanya berdasarkan penggunaan kata yang sesuai dengan zhahir ayat. Hal ini dilakukan karena para ulama muataakkhirin khawatir akan terjadi kerusakan keyakinan ummat, terutama mereka yang belum begitu memahami ilmu agama sehingga ummat akan terjaga dari tindakan menyerupakan Allah dengan makhluk-Nya (tasybih). ${ }^{19}$

Ketiga, mengenai siapa yang boleh menta'wil ayat-ayat mutasyabihat. Dalam konteks kebolehan bagi bagi orang-orang yang hendak menta'wil ada yang mensyaratkan dengan keluasan ilmu, ketinggian ilmu, kemantapan ilmu, kemampuan berpikir yang mendalam dan tajam. Ada pula yang mensyaratkan harus memiliki tingkat spiritualitas yang tinggi dan kedekatan kepada Allah Swt. Dari perbedaan kategori

${ }^{17}$ Ahmad Fuad Effendy, Sudahkah Kita Mengenal Al-Qur'an? (Malang: MISYKAT Indonesia, 2016), 230-231.

${ }^{18}$ Effendy, 231.

${ }^{19}$ Diah Rusmala Dewi and Ghamal Sholeh Hutomo, 'Hikmah Dan Nilai-Nilai Pendidikan Adanya Ayat-Ayat Muhkamat Dan Mutasyabihat Dalam Al-Qur'an', Islamika, 2.1 (2020), 63-83 <https://doi.org/10.36088/islamika.v2i1.426>. 
tersebut, maka timbullah perbedaan mengenai siapa saja yang boleh menta'wil ayat-ayat mutasyabihat. ${ }^{20}$

\section{Nilai Pendidikan dalam Ayat-Ayat Muhkamat dan Mutasyabihat}

Pembagian term muhkam dan mutasyabih berpegaruh dalam banyak aspek, terutama bagi dunia pendidikan. Pendidikan Islam tidak bisa lepas dari Islamic source sebagai basis pengembangan. Al-Qur'an dan Al-Hadits menjadi ruh bagi pendidikan dan pengembangannya. ${ }^{21}$ Dalam sudut pandang dunia pendidikan, terdapat nilai-nilai yang bisa dipetik dari adanya ayat muhkam dan mutasyabih dalam Al-Qur'an. Pertama, nilai toleransi dalam upaya peningkatan kecerdasan emosional. Sikap para ulama dalam menyikapi adanya klasifikasi ayat-ayat Al-Qur'an berdasarkan kedua term ini adalah dengan mereka tidak saling menyalahkan, tetapi saling melengkapi untuk dapat memahami makna yang sebenarnya dari ayat-ayat Al-Qur'an ${ }^{22}$. Dari sikap para ulama tersebut, terdapat nilai pendidikan yang sangat penting, yaitu nilai toleransi. Sikap toleransi ini akan mendorong timbulnya rasa saling menghargai. Nilai toleransi dalam dunia pendidikan akan meningkatkan kecerdasan emosional dari peserta didik.

Kedua, nilai mujahadah dalam upaya peningkatan kecerdasan intelektual. Adanya pembagian kedua term ini menjadi penyebab adanya kajian dan analisis mendalam terhadap ayat-ayat Al-Qur'an. Sehingga timbul nilai mujahadah yang dicontohkan oleh para ulama. Kondisi seperti ini sangat diperlukan dalam dunia pendidikan Islam, karena paradigma pendidikan Islam mengenai ilmu pengetahuan mencakup konsep ontologi, epistemologi, dan aksiologi. Berdasarkan paradigma tersebut, adanya ayat-ayat muhkamat dan mutasyabihat menjadi sebab munculnya ghirah dalam mengkaji ayat-ayat Al-Qur'an, sehingga output dari lembaga pendidikan Islam memiliki kecerdasan intelektual dan mampu menjawab persoalan yang menyentuh ranah ontologi, epistemologi, maupun aksiologi. Ketiga, nilai tauhid dalam upaya peningkatan kecerdasan spiritual. Sikap ulama terutama ulama salaf ketika

\footnotetext{
${ }^{20}$ Effendy, 232-233.

21 Arista Aulia Firdaus, Unik Hanifah Salsabila, and Sarifa Sintia Mahdalina, 'Perubahan Model Dan Karakteristik Pembelajaran Pendidikan Agama Islam Di Masa Pandemi Covid-19', Jurnal Pendidikan Dan Kewirausahaan, 8.2 (2021), 87-97 <https://doi.org/10.47668/pkwu.v8i2.92>.

22 Siti Badiah, 'Hikmah Dan Nilai-Nilai Pendidikan Adanya Ayat-Ayat Muhkamat Dan Mutasyabihat Dalam Al-Qur'an', Al-Dzikra, XI.1 (2017), 107-23.
} 
menghadapi ayat-ayat yang sulit dihami maknanya adalah dengan mengembalikannya kepada Allah, seperti makna dari ayat-ayat yang menjadi fawatih al-suwar. ${ }^{23}$ Sikap berserah diri kepada Allah memiliki nilai tauhid yang sangat penting demi meningkatkan kecerdasan spiritual peserta didik. Sehingga dalam perjalanannya peserta didik tidak memiliki karakter yang angkuh dan selalu merasa lebih dihadapan orang lain. Nilai tauhid akan membentuk karakter mereka menjadi pribadi yang rendah hati.

Keempat, nilai pendidikan kontekstual. Pembagian kedua term ini memudahkan ummat untuk memahami ayat-ayat Al-Qur'an meskipun itu dari golongan orang-orang awam. Artinya Al-Qur'an sangat fleksibel untuk difahami oleh semua kalangan. Konsep ini merupakan nilai pendidikan yang sangat penting. Dalam upaya memberikan pembelajaran, seorang guru harus bisa menyesuaikan diri dengan kondisi peserta didik. Ilmu yang disampaikan oleh guru tersebut harus disesuaikan dengan tingkat pemahaman dan kehidupan sehari-sehari peserta didik. Kemudian ilmu yang didapatkan oleh peserta didik tidak hanya dikonsumsi dalam bentuk teori, tapi dipraktikkan dalam kehidupan mereka masing-masing.

Nilai-nilai pendidikan dari adanya klasifikasi term muhkam dan mutasyabih tidak hanya diperuntukkan bagi siswa, akan tetapi juga harus dimaknai oleh guru yang berperan sebagai tenaga pendidik. Peningkatan kecerdasan baik itu kecerdasan emosional, intelektual, maupun spiritual memang sangat sangat diperlukan oleh peserta didik. Dalam proses pembelajaran, tidak cukup hanya siswa yang memiliki kecerdasan, guru pun harus memiliki ketiga kecerdasan tersebut. Bagi guru adanya term muhkam dan mutasyabih bukan hanya untuk meningkatkan kecerdasan emosional, intelektual, maupun spiritual, tapi nilai implementasi pendidikan konteksual harus bisa difahami dan dipraktikkan oleh guru. Guru harus mampu mengerti kondisi dari siswanya agar ilmu yang disampaikan dapat difahami dan dipraktikkan dengan mudah oleh peserta didik.

${ }^{23}$ Ichwan, 269. 


\section{Kesimpulan}

Ayat-ayat muhkam adalah ayat-ayat yang dapat difahami dengan mudah lafadz dan maknanya, sehingga tidak perlu melakukan analisis yang mendalam untuk menggali maksud dari ayat tersebut. Adapun ayat-ayat mutasyabih adalah ayat-ayat yang sulit untuk difahami lafadz dan maknanya jika tidak dilakukan analisis secara mendalam.

Ayat-ayat muhkamat adalah seluruh ayat Al-Qur'an yang rapi dan terperinci, dan ayat-ayat mutasyabihat diklasifikasi menjadi 3 kondisi yaitu, tasyābuh pada lafal ayat, tasyābuh pada makna ayat, tasyābuh pada lafal dan makna ayat sekaligus. Implikasi dari adanya ayat-ayat muhkamat dan mutasyabihat bagi peradaban dunia Islam adalah menjadi titik balik perkembangan peradaban dalam aspek ilmu pengetahuan, aspek dakwah, dan terutama aspek spiritualitas.

Perbedaan pandangan ulama dalam menyikapi adanya klasifikasi ayat-ayat muhkamat dan mutasyabihat adalah terletak pada tiga konteks, yaitu mengenai penentuan ayat-ayat muhkamat dan mutasyabihat, mengenai boleh tidaknya mentakwil ayat, dan mengenai siapa yang boleh menta'wil ayat-ayat mutasyabihat.

Nilai-nilai pendidikan dari adanya klasifikasi term muhkam dan mutasyabih adalah peningkatan kecerdasan siswa baik itu kecerdasan emosional, intelektual, maupun spiritual. Bukan hanya bagi siswa, tapi adanya ayat-ayat tersebut memiliki nilai pendidikan bagi guru yang harus mampu mengerti dan menerapkan model pembelajaran kontekstual. 


\section{Daftar Pustaka}

Arif, Mahmud, Tafsir Pendidikan Makna Edukasi Alquran Dan Aktualisasi Pembelajarannya (Yogyakarta: Penerbit Ombak, 2015)

Badiah, Siti, 'Hikmah Dan Nilai-Nilai Pendidikan Adanya Ayat-Ayat Muhkamat Dan Mutasyabihat Dalam Al-Qur'an', Al-Dzikra, XI.1 (2017), 107-23

Dewi, Diah Rusmala, and Ghamal Sholeh Hutomo, 'Hikmah Dan Nilai-Nilai Pendidikan Adanya Ayat-Ayat Muhkamat Dan Mutasyabihat Dalam AlQur'an', $\quad$ Islamika, $\quad 2.1 \quad$ (2020), $\quad 63-83$ <https://doi.org/10.36088/islamika.v2i1.426>

Drajat, Amroeni, Ulumul Qur’an Full Pengantar Ilmu-Ilmu Al-Qur'an, 1st edn (Depok: KENCANA, 2017)

Effendy, Ahmad Fuad, Sudahkah Kita Mengenal Al-Qur'an? (Malang: MISYKAT Indonesia, 2016)

Firdaus, Arista Aulia, Unik Hanifah Salsabila, and Sarifa Sintia Mahdalina, 'Perubahan Model Dan Karakteristik Pembelajaran Pendidikan Agama Islam Di Masa Pandemi Covid-19', Jurnal Pendidikan Dan Kewirausahaan, 8.2 (2021), 87-97 <https://doi.org/10.47668/pkwu.v8i2.92>

Ichwan, Mohammad Nor, Memahami Bahasa Al-Qur'an, 2nd edn (Yogyakarta: Pustaka Pelajar, 2018)

Ilyas, Yunahar, Kuliah Ulumul Qur'an, 3rd edn (Yogyakarta: ITQAN Publishing, 2014)

Melfianora, 'Penulisan Karya Tulis Ilmiah Dengan Studi Literatur', Open Science Framework, 2019

Mukarromah, Oom, Ulumul Qur'an (Jakarta: PT RajaGrafindo Persada, 2013)

Rohman, Miftahur, 'Konsep Muhkam Dan Mutasyabih Dalam Alqur'an Menurut Muhammad 'Abid Al-Jabiri', Hermeneutik, 12.1 (2019), 175-88 <https://doi.org/10.21043/hermeneutik.v12i1.6072>

Sarwat, Ahmad, Muhkam Dan Mutasyabih (Jakarta Selatan: Rumah Fiqih Publishing, 2020) 